\author{
MAGDALENA MALESIŃSKA \\ Uniwersytet Mikołaja Kopernika w Toruniu \\ magdalena malesinska@onet.pl
}

\title{
Odpowiedzialność odszkodowawcza pracodawcy za naruszenie zasady równego traktowania $\mathrm{w}$ zatrudnieniu
}

\author{
Employers' compensation liability for abusing of the principle of equal treatment in \\ employment and occupation
}

Streszczenie. Celem niniejszego artykułu jest przedstawienie regulacji prawnych dotyczących odpowiedzialności odszkodowawczej pracodawcy za naruszenie zasady równego traktowania w zatrudnieniu. Wprowadzenie wyżej wspomnianych przepisów związane było z koniecznością dostosowania polskich regulacji prawnych do przepisów unijnych. Opierając się na doktrynie i orzecznictwie, przedstawiono zakres przedmiotowy i podmiotowy regulacji, zarysowano różnicę między zasadą równego traktowania i niedyskryminacji oraz wyliczono przypadki zgodnego z prawem różnicowania pozycji prawnej pracowników. Opracowanie zawiera ponadto omówienie przesłanek uaktualnienia się odpowiedzialności odszkodowawczej pracodawcy za naruszenie zakazu dyskryminacji w zatrudnieniu oraz cechy rekompensaty przewidzianej w art. $18^{3 \mathrm{~d}} \mathrm{k} . \mathrm{p}$.

Słowa kluczowe: zasada równego traktowania w zatrudnieniu; zasada niedyskryminacji; odpowiedzialność odszkodowawcza pracodawcy za dyskryminację w zatrudnieniu.

\begin{abstract}
The aim of this article is to explain the legal regulations associated with the employers' compensation liability for abusing of the principle of equal treatment in employment and occupation. The enactment of abovementioned provisions was related to the necessity of adaptation of polish legal regulations to the UE law. Based on the judicial decisions and the legal doctrine, the article illustrates the subjective and personal scope of the regulation, explains what is the difference between the equal treatment and non-discrimination and enumerates the circumstances in which the unequal treatment of the employees is consistent with the law. Moreover, the analysis clarifies when the conditions of employers' compensation liability are fulfilled and illustrates the features of the damages provided under the provision $18^{3 \mathrm{~d}}$ of the Polish Labour Code.
\end{abstract}

Keywords: the principle of equal treatment in employment; the non-discrimination principle; the employers' compensation liability for discrimination in employment and occupation.

\section{Wstęp}

Zasady równości i niedyskryminacji są jednymi z najbardziej fundamentalnych zasad prawnych w państwach demokratycznych. Polska Konstytucja z 1997 r. ${ }^{1}$ w art. 32 ust. 1 stanowi, że „Wszyscy są wobec prawa równi. Wszyscy mają prawo do równego traktowania przez władze publiczne” (zasada równości), natomiast w ust. 2: „Nikt nie może być

\footnotetext{
${ }^{1}$ Konstytucja Rzeczypospolitej Polskiej z dnia 2 kwietnia 1997 r. (Dz.U. Nr 78, poz. 483).
} 
dyskryminowany w życiu politycznym, społecznym lub gospodarczym z jakiejkolwiek przyczyny" (zasada niedyskryminacji).

Odpowiednikiem i uszczegółowieniem konstytucyjnej zasady równości w prawie pracy jest zawarta w art. $11^{2}$ Kodeksu Pracy ${ }^{2}$ (zwanego dalej „KP”) regulacja, w której ustawodawca stanowi, że: „Pracownicy mają równe prawa z tytułu jednakowego wypełniania takich samych obowiązków; dotyczy to w szczególności równego traktowania mężczyzn i kobiet w zatrudnieniu". Ponadto w art. $11^{3} \mathrm{KP}$ ustanowiono zakaz dyskryminacji W zatrudnieniu (zasadę niedyskryminacji): „Jakakolwiek dyskryminacja w zatrudnieniu, bezpośrednia lub pośrednia, w szczególności ze względu na płeć, wiek, niepełnosprawność, rasę, religię, narodowość, przekonania polityczne, przynależność związkową, pochodzenie etniczne, wyznanie, orientację seksualną, a także ze względu na zatrudnienie na czas określony lub nieokreślony albo $\mathrm{w}$ pełnym lub w niepełnym wymiarze czasu pracy - jest niedopuszczalna”. Katalog przyczyn mogących prowadzić do nierównego traktowania jest otwarty. Bardziej szczegółowo kwestia równego traktowania w zatrudnieniu została unormowana w rozdziale IIa Kodeksu Pracy w art. $18^{3 \mathrm{a}}-18^{3 \mathrm{e}}$.

W polskim prawie brak jest legalnej definicji pojęcia „dyskryminacja”. Mając powyższe na uwadze, do zakazu dyskryminacji uzupełniająco stosuje się przepisy dotyczące obowiązku równego traktowania w zatrudnieniu ${ }^{3}$. Definicja taka została jednak wypracowana przez judykaturę - dyskryminację w sferze zatrudnienia definiuje się ogólnie jako „,bezprawne pozbawienie lub ograniczenie praw wynikających ze stosunku pracy albo nierównomierne traktowanie pracowników ze względu na wymienione w przepisie kryteria dyskryminacyjne, a także przyznawanie $\mathrm{z}$ tych względów niektórym pracownikom mniejszych praw niż te, z których korzystają inni pracownicy, znajdujący się w takiej samej sytuacji faktycznej i prawnej. Nie narusza jednak zasady równości usprawiedliwione i racjonalne zróżnicowanie (dyferencjacja) sytuacji prawnej podmiotów ze względu na różniącą je cechę istotną (relewantną)"4.

Należy podkreślić, iż art. $18^{3 \mathrm{a}} \mathrm{KP}$ odnosi się tylko do sytuacji, w której między podmiotami prawa istnieje stosunek pracy $^{5}$, zatem nie będzie miał zastosowania do umów, na podstawie których wprawdzie powstaje obowiązek świadczenia pracy, jednak między stronami nie powstaje stosunek pracy w znaczeniu art. $22 \S 1 \mathrm{KP}$. Warto dodać, że powyższe

\footnotetext{
${ }^{2}$ Ustawa z dnia 26 czerwca 1974 r. Kodeks pracy (tekst jedn.: Dz.U. 2014 poz. 1502).

${ }^{3}$ A. M. Świątkowski, Kodeks pracy. Komentarz, Warszawa 2012, s. 63.

${ }^{4}$ Wyrok SN z dnia 10 maja 2012 r., II PK 227/11, OSNP 2013, nr 9-10, poz. 107.

${ }^{5}$ J. Iwulski, W. Sanetra, Kodeks Pracy. Komentarz, Warszawa 2013, s. 133.
} 
przepisy mają zastosowanie do wszystkich sfer stosunku pracy, tj. do jego nawiązania, realizacji i ustania ${ }^{6}$.

\section{Odpowiedzialność odszkodowawcza pracodawcy w świetle prawa UE}

Odniesienia do zasady równości i niedyskryminacji znajdują się w licznych aktach normatywnych Unii Europejskiej, np. w Karcie Praw Podstawowych Unii Europejskiej ${ }^{7}$ (art. 20, art. 21 i art. 23), która ma taką samą moc jak Traktaty Europejskie ${ }^{8}$, w Traktacie o Unii Europejskiej $^{9}$ (art. 2) czy Traktacie o funkcjonowaniu Unii Europejskiej ${ }^{10}$ (m.in. art. 8, art. 10, art. 153 ust 1 lit i oraz art. 157).

Dla pełniejszej realizacji postulatów wyrażonych we wcześniej przytoczonych przepisach wydany został cały szereg dyrektyw unijnych, które mają na celu implementację do prawa krajowego określonych standardów w zakresie ochrony pracownika przed dyskryminacją i zapewnienia mu rzeczywistego prawa do równego traktowania W zatrudnieniu. W obecnym stanie prawnym na szczególną uwagę zasługują trzy dyrektywy: dyrektywa Rady nr 2000/43/WE z dnia 29 czerwca 2000 r. wprowadzająca w życie zasadę równego traktowania osób bez względu na pochodzenie rasowe lub etniczne ${ }^{11}$, dyrektywa Rady nr 2000/78/WE z dnia 27 listopada 2000 r. ustanawiająca ogólne warunki ramowe równego traktowania $\mathrm{w}$ zakresie zatrudnienia $\mathrm{i}$ pracy ${ }^{12}$ oraz dyrektywa Parlamentu Europejskiego i Rady nr 2006/54/WE z dnia 5 lipca 2006 r. w sprawie wprowadzenia w życie zasady równości szans oraz równego traktowania kobiet i mężczyzn w dziedzinie zatrudnienia i pracy (wersja przeredagowana) ${ }^{13}$.

Zgodnie z treścią wyżej przytoczonych przepisów unijnych, Państwa Członkowskie zobowiązane są do ustanowienia sankcji za naruszenie zasady równego traktowania oraz podjęcia wszelkich środków dla zapewnienia ich stosowania. Sankcje, o których mowa, winny być skuteczne, proporcjonalne do poniesionej szkody lub doznanej krzywdy, odstraszające i dolegliwe ${ }^{14}$.

\footnotetext{
${ }^{6}$ K. W. Baran (red.), Kodeks Pracy. Komentarz, Warszawa 2014, s. 100.

${ }^{7}$ Dz.Urz. UE C 326 z 26.10.2012, s. 391.

${ }^{8}$ Zgodnie z art. 6 ust 1 Traktatu o Unii Europejskiej.

${ }^{9}$ Traktat o Unii Europejskiej - wersja skonsolidowana (Dz.Urz. UE C 326 z 26.10.2012, s. 13).

${ }^{10}$ Traktat o funkcjonowaniu Unii Europejskiej - wersja skonsolidowana (Dz.Urz. UE C 326 z 26.10.2012, s. 47).

${ }^{11}$ Dz.Urz. UE L 180 z 19.07.2000, s. 22.

${ }^{12}$ Dz.Urz. UE L 303 z 02.12.2000, s. 16.

${ }_{13}^{13}$ Dz.Urz. UE L 204 z 26.07.2006, s. 23.

${ }^{14}$ Zgodnie z treścią art. 15 dyrektywy 2000/43/WE, art. 17 dyrektywy 2000/78/WE i art. 18 dyrektywy 2006/54/WE.
} 


\section{Odpowiedzialność odszkodowawcza pracodawcy na podstawie art. $18^{3 \mathrm{~d}}$ Kodeksu Pracy}

\section{Uwagi ogólne}

Konieczność dostosowania prawa polskiego do prawa Unii Europejskiej, zwłaszcza implementacji dyrektyw wymienionych w punkcie II, doprowadziła do uchwalenia w dniu 14 listopada 2003 r. ustawy o zmianie ustawy - Kodeks Pracy oraz o zmianie niektórych innych ustaw $^{15}$. Na mocy nowelizacji do KP dodany został rozdział IIa zatytułowany „Równe traktowanie w zatrudnieniu", obejmujący swoim zakresem art. $18^{3 \mathrm{a}}-18^{3 \mathrm{e}}$.

Zgodnie $\mathrm{z}$ art. $18^{3 \mathrm{~d}} \mathrm{KP}$, „Osoba, wobec której pracodawca naruszył zasadę równego traktowania $\mathrm{w}$ zatrudnieniu, ma prawo do odszkodowania $\mathrm{w}$ wysokości nie niższej niż minimalne wynagrodzenie za pracę, ustalane na podstawie odrębnych przepisów”.

Roszczenie $\mathrm{z}$ art. $18^{3 \mathrm{~d}} \mathrm{KP}$ przysługuje jedynie osobie, wobec której naruszona została zasada równego tratowania $\mathrm{w}$ zatrudnieniu (zwykle pracownikowi, ewentualnie niedoszłemu lub byłemu pracownikowi), a odpowiedzialność ponosi pracodawca. Jednakże przyjmuje się zwykle, iż pracodawca ponosi również odpowiedzialność za zachowania dyskryminacyjne zatrudnionych przez siebie pracowników ${ }^{16}$.

Ponadto, dyskryminacja pracownika, wynikająca $\mathrm{z}$ zachowania pracodawcy o charakterze ciągłym, może być podstawą przyznania tylko jednego zadośćuczynienia, a przepis art. $18^{3 \mathrm{~d}} \mathrm{KP}$ nie jest podstawą zasądzenia odszkodowania za szkodę mogącą wystąpić w przyszłości ${ }^{17}$.

\section{Przesłanki odpowiedzialności}

Przesłanką przyznania odszkodowania, o którym mowa w art. $18^{3 \mathrm{~d}}$, jest bezprawne naruszenie przez pracodawcę zasady równego traktowania ${ }^{18}$. Nie wymaga się natomiast świadomości dokonania naruszenia przepisów prawnych czy winy $\mathrm{w}$ znaczeniu subiektywnym ${ }^{19}$.

\footnotetext{
${ }^{15}$ Ustawa z dnia 14 listopada 2003 r. o zmianie ustawy - Kodeks Pracy oraz o zmianie niektórych innych ustaw (Dz.U. $2003 \mathrm{nr} 213$ poz. 2081).

${ }_{16}$ P. Czarnecki, Charakter prawny odszkodowania za dyskryminacje w zatrudnieniu, „Praca i Zabezpieczenie Społeczne" 2012, nr 2 oraz przywołana tam literatura. Pewne wątpliwości w tym względzie i szersze omówienie zagadnienia: A. Sobczyk (red.), Kodeks pracy. Komentarz, , Warszawa 2015, s. 79-80. Wydaje się, że, inaczej niż w przypadku odpowiedzialności za działania własne, pracodawca ponosi tu odpowiedzialność za zasadzie winy.

${ }^{17}$ Wyrok SN z dnia 7 stycznia 2009 r., III PK 43/08, OSNP 2010, nr 13-14, poz. 160.

${ }^{18}$ J. Iwulski, W. Sanetra, Kodeks Pracy ...., s. 149; tak również K. W. Baran (red.), Kodeks pracy. Komentarz, s. $154-155$.

${ }_{19}$ J. Iwulski, W. Sanetra, Kodeks Pracy. Komentarz, s. 149, także A. Sobczyk (red.), Kodeks pracy. Komentarz, s. 80.
} 
Nieco inny pogląd zdaje się wyrażać Andrzej Świątkowski, który pisze, że: ”Akt dyskryminacji w zatrudnieniu jest świadomym aktem pracodawcy. Akt dyskryminacji bezpośredniej może być popełniony $\mathrm{z}$ winy umyślnej, $\mathrm{z}$ zamiarem bezpośrednim lub ewentualnym. Aktu pośredniej dyskryminacji można dopuścić się z winy nieumyślnej, wówczas gdy pracodawca nie przewiduje, że pozornie neutralne kryterium różnicowania pracowników wywołuje ujemne następstwa wyłącznie wobec osób określonej kategorii społecznej, np. jednej płci”20. Zgadzając się z poglądem Autora, iż nastawienie psychiczne sprawcy winno być brane pod uwagę przez sąd podczas ustalania wysokości odszkodowania za dyskryminację ${ }^{21}$, trudno uznać, że świadomość czy wina pracodawcy jest przesłanką jego odpowiedzialności, zwłaszcza że, jak już wcześniej w niniejszym opracowaniu wspomniano, pracodawca ponosi również odpowiedzialność za zachowania dyskryminacyjne, których dopuścili się zatrudnieni przez niego pracownicy i to bez względu na to, czy o występowaniu tych zachowań wiedział, czy nie ${ }^{22}$. Ponadto, biorąc pod uwagę to, że przepisy dotyczące równego tratowania $\mathrm{w}$ zatrudnieniu zostały dostosowane do regulacji prawa Unii Europejskiej i winny być z nimi zgodne, istotne znaczenie ma wyrok Trybunału Sprawiedliwości Unii Europejskiej C-177/88 z dnia 8 listopada 1990 r. w sprawie Dekker, w którym stwierdzono, że ,przepisy dyrektywy nie uzależniają odpowiedzialności pracodawcy od winy lub innych okoliczności wyłączających odpowiedzialność według prawa krajowego"23.

Przesłanką negatywną odpowiedzialności pracodawcy jest natomiast wystąpienie kontratypu bezprawności. Sytuacje, w których nierówne traktowanie pracowników jest dopuszczalne, przewidziane zostały w art. $18^{3 \mathrm{~b}} \S 2-4 \mathrm{KP}$.

Ponadto, mając na uwadze różnorodność stanów faktycznych, jakie mogą wystąpić w czasie obowiązywania omawianej regulacji, ustawodawca umożliwił pracodawcy uwolnienie się od odpowiedzialności odszkodowawczej, przerzucając na niego ciężar udowodnienia, że kierował się on obiektywnymi powodami, działając w sytuacji, w której pracownik uprawdopodobni, iż naruszona została w stosunku do niego zasada równości lub niedyskryminacji w zatrudnieniu ${ }^{24}$.

Z przedstawionych wyżej regulacji jasno wynika, że ustawodawca nie wyklucza różnicowania sytuacji pracowników. Odrębności w traktowaniu muszą być jednak

\footnotetext{
${ }^{20}$ A. M. Świątkowski, Kodeks pracy. Komentarz, s. 105.

${ }^{21}$ Tamże, s. 105.

${ }^{22}$ K. Kędziora, K. Śmiszek, Dyskryminacja i mobbing w zatrudnieniu, Warszawa 2008, s. 207.

${ }^{23} \mathrm{Za}$ : K. Jaśkowski, Kilka uwag o odszkodowaniu za dyskryminację pracownika (art. $18^{d 3} \mathrm{KP}$ ), w: Z aktualnych zagadnień prawa pracy i zabezpieczenia społecznego. Księga jubileuszowa profesora Waleriana Sanetry, Białystok 2013, s. 176.

${ }^{24}$ J. Iwulski, W. Sanetra, Kodeks pracy. Komentarz, Warszawa 2011, s. 180.
} 
usprawiedliwione występowaniem którejś w wymienionych okoliczności (kontratypy bezprawności).

\section{Wysokość odszkodowania i jego charakter}

Zgodnie z dyspozycją art. $18^{3 \mathrm{~d}} \mathrm{KP}$, osoba, wobec której pracodawca naruszył zasadę równego traktowania $\mathrm{w}$ zatrudnieniu, ma prawo do odszkodowania w wysokości nie niższej niż minimalne wynagrodzenie za pracę, ustalane na podstawie odrębnych przepisów. Co istotne, również $\mathrm{w}$ razie zawarcia ugody przed sądem nie jest możliwe ustalenie kwoty odszkodowania niższej niż wysokość minimalnego wynagrodzenia ${ }^{25}$. De lege lata przepisy nie przewidują maksymalnej wysokości odszkodowania ${ }^{26}$ (do 2003 r. nie mogło ono przekroczyć kwoty równej sześciokrotności minimalnego wynagrodzenia na pracę).

Ustawodawca nie formułuje również dyrektyw, którymi winny kierować się sądy, ustalając wysokość należnego odszkodowania. Wskazówką dla sądów podczas orzekania o wysokości świadczenia powinny być przepisy dyrektyw unijnych - m.in. art. 15 dyrektywy 2000/43 oraz art. 17 dyrektywy 2000/78, o których była już wcześniej mowa. Warto przypomnieć, że dyrektywy te przewidują, iż sankcje za naruszenie zasady równego traktowania w zatrudnieniu winny być „skuteczne, proporcjonalne i odstraszające”.

Ponadto, ułatwienie stanowić może również orzecznictwo i doktryna. Zgodnie z nimi, na wysokość odszkodowania, o którym mowa w art. $18^{3 \mathrm{~d}} \mathrm{KP}$, ma wpływ rodzaj i intensywność działań dyskryminujących ${ }^{27}$. Według A. M. Świątkowskiego, znaczenie ma również rodzaj chronionego dobra, naruszonego przez pracodawcę dyskryminującego pracownika $^{28}$. W orzecznictwie podkreśla się, że "ustalając wysokość odszkodowania, należy brać pod uwagę okoliczności dotyczące obu stron stosunku pracy”"29. Nadto, w razie uzyskiwania zbyt niskiego wynagrodzenia z powodu naruszenia przez pracodawcę zasady równego traktowania w zatrudnieniu, pracownik może domagać się wyrównania poniesionej przez niego szkody. Szkoda ta obejmuje jednak nie tylko różnicę między otrzymywanym a należnym zgodnie z prawem zasadniczym wynagrodzeniem, ale również utracone korzyści wynikające $\mathrm{z}$ uzyskanych $\mathrm{w}$ zbyt niskiej kwocie składników wynagrodzenia, których wysokość zależna jest od płacy zasadniczej ${ }^{30}$.

Pewne rozbieżności $\mathrm{w}$ doktrynie $\mathrm{i}$ orzecznictwie pojawiają się na tle zagadnienia charakteru prawnego odszkodowania za naruszenie zasady równości w zatrudnieniu.

\footnotetext{
${ }^{25}$ M. T. Romer, Kodeks pracy. Komentarz, Warszawa 2010, s. 181.

${ }^{26}$ Tamże, s. 181.

${ }^{27}$ Wyrok SN z dnia 3 kwietnia 2008 r., II PK 286/07, OSNP 2009, nr 15-16, poz. 202.

${ }^{28}$ A. M. Świątkowski, Kodeks pracy. Komentarz, s. 104.

${ }^{29}$ Wyrok SN z dnia 7 stycznia 2009 r., III PK 43/08, OSNP 2010, nr 13-14, poz. 160.

${ }^{30}$ M. Tomaszewska, w: K. W. Baran (red.), Kodeks pracy. Komentarz ..., s. 156.
} 
Wyróżnić można dwa dominujące poglądy: zgodnie z pierwszym z nich zasadniczą funkcją odszkodowania $\mathrm{z}$ art. $18^{3 \mathrm{~d}} \mathrm{KP}$ jest naprawienie uszczerbku w dobrach majątkowych, drugie stanowisko stanowi, iż wspomniane świadczenie odszkodowawcze obejmuje swoim zakresem zarówno wyrównanie szkody majątkowej, jak i zadośćuczynienie doznanej krzywdzie ${ }^{31}$. Jednym z głównych źródeł rozbieżności jest dwojakie rozumienie pojęcia „szkody” na gruncie prawa cywilnego - w znaczeniu wąskim obejmuje ona jedynie szkodę w dobrach majątkowych, w szerszym znaczeniu zarówno krzywda, jak i zadośćuczynienie, stanowią szczególną postać szkody i odszkodowania ${ }^{32}$. Co istotne, w KP pojawiają się również inne przypadki, w których niemal zacierają się różnice między odszkodowaniem a zadośćuczynieniem (np. zadośćuczynienie za mobbing z art. $\left.94^{3} \S 3 \mathrm{KP}\right)^{33}$.

Ponadto, Sąd Najwyższy w swoich orzeczeniach przesądził, że: „odszkodowanie, o którym mowa w art. $18^{3 \mathrm{~d}} \mathrm{KP}$, obejmuje wyrównanie uszczerbku w dobrach majątkowych

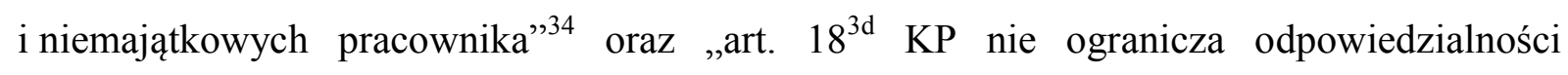
pracodawcy do szkody w mieniu pracownika, a więc obejmuje ona także szkodę na osobie i naruszenie dóbr osobistych pracownika ${ }^{35}$. Co więcej, w dalszej części uzasadnienia cytowanego wyroku sąd wyraźnie wskazuje, iż ,jeżeli dyskryminacja pracownika nie powoduje szkody majątkowej lub szkoda ta jest niższa od minimalnego wynagrodzenia, to pracownik ma prawo do odszkodowania (będącego - odpowiednio - tylko zadośćuczynieniem lub częściowo także odszkodowaniem sensu stricto)”.

Wydaje się, że wspomnianą kwestię należy analizować ad casum. Nie można bowiem wykluczyć, że w konkretnym przypadku przeważające znaczenie będzie miała poniesiona szkoda majątkowa, w innym natomiast pracownik w wyniku zachowania o podłożu dyskryminacyjnym nie poniesie wprawdzie dużego uszczerbku majątkowego, ale dozna znacznej krzywdy. Pogląd ten wydaje się uzasadniony również $\mathrm{w}$ zestawieniu $\mathrm{z}$ treścią art. $18^{3 \mathrm{~d}} \mathrm{KP}$, w którym ustawodawca przewidział minimalną kwotę odszkodowania za dyskryminację w zatrudnieniu. Jasne jest, że nie za każdym razem pracownik poniesie szkodę w minimalnej wysokości. W takich okolicznościach przyjęcie, że odszkodowanie obejmuje jedynie szkodę w dobrach majątkowych, byłoby sprzeczne z literalnym brzmieniem przepisu. Należałoby zatem skłonić się ku stanowisku, że przynajmniej w przypadkach, kiedy szkoda

\footnotetext{
${ }^{31}$ M. Lewandowski, Ochrona pracownika przed dyskryminacja w polskim prawie pracy, „Palestra” 2014, nr 3-4.

${ }^{32}$ Z. Radwański, A. Olejniczak, Zobowiązania - część ogólna, Warszawa 2012, s. 91.

${ }^{33}$ P. Czarnecki, Charakter prawny odszkodowania za dyskryminację ..., s. 18

${ }^{34}$ Wyrok SN z dnia 7 stycznia 2009 r., III PK 43/08, OSNP 2010, nr 13-14, poz. 160.

${ }^{35}$ Wyrok SN z dnia 14 lutego 2013 r., III PK 31/12, LEX nr 1380964.
} 
majątkowa jest mniejsza niż minimalna kwota wynagrodzenia, w pojęciu odszkodowania za dyskryminację mieści się również element niekompensacyjny.

Kolejne wątpliwości pojawiają się $\mathrm{w}$ odniesieniu do konieczności zaistnienia jakiejkolwiek szkody po stronie pracownika dla przyznania przez sąd odszkodowania $z$ art. $18^{3 \mathrm{~d}}$ KP. Według Teresy Liszcz, odszkodowanie za naruszenie zasady równego traktowania w zatrudnieniu nie zależy od poniesienia szkody przez pracownika, a związane jest $z$ samą bezprawnością działania pracodawcy ${ }^{36}$. Podobne stanowisko, uniezależniające fakt zaistnienia szkody od przyznania pracownikowi rekompensaty wyrazili również m.in. K. Kędziora i K. Śmiszek ${ }^{37}$. Także orzecznictwo Sądu Najwyższego skłania się ku tezie, że przepis art. $18^{3 \mathrm{~d}} \mathrm{KP}$ „nie wiąże odszkodowania z poniesieniem szkody majątkowej”38. Spór ten związany jest $\mathrm{W}$ znacznej mierze $\mathrm{z}$ omawianym już powyżej problemem niekompensacyjności odszkodowania za naruszenie zasady równego traktowania w zatrudnieniu. Sporne jest w takiej sytuacji, czy „dopełnieniem” kwoty odszkodowania do minimalnej kwoty wynagrodzenia (a nawet całą kwotą rekompensaty) będzie zadośćuczynienie za poniesioną krzywdę czy swoistego rodzaju kara dla pracodawcy za bezprawne zachowanie. Niezależnie jednak od rozstrzygnięcia tego sporu, o ile pracownik domaga się odszkodowania $\mathrm{w}$ kwocie minimalnej, nie wymaga się od niego wykazania poniesionej szkody ${ }^{39}$, a jedynie fakt wystąpienia zdarzenia dyskryminacyjnego.

Inne stanowisko w tej kwestii wyraża Walerian Sanetra, który, kierując się cywilistycznym znaczeniem odszkodowania, łączy jego przyznanie z zaistnieniem szkody i adekwatnego związku przyczynowego między zdarzeniem kreującym odpowiedzialność odszkodowawczą a zaistniałą szkodą ${ }^{40}$.

Warto zaznaczyć, że ustawodawca nie po raz pierwszy przewiduje w KP instytucję, w której przyznanie odszkodowania jest niezależne od zaistnienia jakiejkolwiek szkody po

\footnotetext{
${ }^{36}$ T. Liszcz, Prawo pracy, Warszawa 2009, s. 326.

${ }^{37}$ K. Kędziora, K. Śmiszek, Dyskryminacja i mobbing $w$ zatrudnieniu ..., s. 208; tak również M. T. Romer, Kodeks pracy. Komentarz ..., s. 181; M. Tomaszewska, w: K. W. Baran (red.), Kodeks pracy. Komentarz ..., s. 155.

${ }^{38}$ Wyrok SN z dnia 3 kwietnia 2008 r., II PK 286/07, LEX nr 511691.

${ }^{39}$ K. Kędziora, K. Śmiszek, Dyskryminacja i mobbing $w$ zatrudnieniu ..., s. 208.

40 J. Iwulski, W. Sanetra, Kodeks Pracy. Komentarz, s. 151; również P. Korus (Komentarz do kodeksu pracy, red. A. Sobczyk, s. 80-81) jako przesłankę odpowiedzialności odszkodowawczej wskazuje zaistnienie szkody i adekwatnego związku przyczynowego pomiędzy naruszeniem zasady równego traktowania w zatrudnieniu przez pracodawcę a szkodą. W dalszych rozważaniach zauważa jednak, że de lege lata przepisy nie wymagają poniesienia szkody dla aktualizacji odpowiedzialności odszkodowawczej pracodawcy, uznając to za rozwiązanie wadliwe.
} 
stronie pracownika (np. roszczenie pracownika w razie wadliwego wypowiedzenia lub rozwiązania umowy o pracę bez wypowiedzenia przez pracodawcę) ${ }^{41}$.

\section{Postępowanie sądowe}

Odszkodowanie przewidziane $\mathrm{w}$ art. $18^{3 \mathrm{~d}} \mathrm{KP}$ może być dochodzone jedynie przed sądem pracy. Jest to sprawa o roszczenia ze stosunku pracy (art. $476 \S 1$ pkt 1 Kodeksu Postępowania Cywilnego $^{42}$ - zwanego dalej KPC). Wątpliwości pojawiają się jedynie w przypadku, gdy dyskryminacja polegała na odmowie zatrudnienia pracownika z przyczyn dyskryminacyjnych, ponieważ między stronami nie dochodzi do nawiązania stosunku pracy. Wydaje się jednak, iż wyżej wspomnianą sytuację również należy zaliczyć do spraw z zakresu prawa pracy. Za poprawnością takiej tezy przemawia przede wszystkim umiejscowienie omawianych przepisów dotyczących dyskryminacji w KP. Co więcej, zgodnie $\mathrm{z}$ art. $476 \S 1$ pkt 2 KPC przez sprawy z zakresu prawa pracy rozumie się również sprawy o roszczenia z innych stosunków prawnych, do których z mocy odrębnych przepisów stosuje się przepisy prawa pracy. A minori ad maius, katalog ten obejmuje również sprawy o roszczenia $\mathrm{z}$ innych stosunków prawnych, które uregulowane zostały w $\mathrm{KP}^{43}$. Ponadto, jak pisze M. P. Wójcik, do spraw z zakresu prawa pracy należy zaliczyć „roszczenia mające źródło w stosunku pracy - mającym powstać, istniejącym lub zakończonym, niezależnie od jego podstawy"44. Warto dodać, że w doktrynie wskazuje się, iż definicja legalna spraw z zakresu prawa pracy celowo została ujęta w sposób szeroki, a zabieg ten miał na celu rozszerzenie kompetencji sądów pracy. Konsekwencją tak sformułowanej definicji jest swoiste domniemanie właściwości sądu pracy, jeśli przepis szczególny wyraźnie nie wskazuje na właściwość innego organu bądź sądu w danej sprawie ${ }^{45}$.

\section{Odszkodowanie $z$ art. $18^{3 \mathrm{~d}}$ Kodeksu Pracy a inne roszczenia odszkodowawcze}

Odszkodowanie przewidziane $\mathrm{w}$ art. $18^{\mathrm{d}}$ nie wyczerpuje katalogu możliwych konsekwencji związanych $\mathrm{z}$ naruszeniem zasady równego traktowania $\mathrm{w}$ zatrudnieniu przez pracodawcę. Pracownik może bowiem skorzystać również z prawa przewidzianego w art. 55 $\S 1^{1} \mathrm{KP}$, a zatem rozwiązać umowę o pracę bez wypowiedzenia $\mathrm{z}$ powodu ciężkiego naruszenia przez pracodawcę podstawowych obowiązków wobec pracownika ${ }^{46}$. Przez ciężkie naruszenie podstawowych obowiązków należy w tym przypadku rozumieć „,naruszenie

\footnotetext{
${ }^{41}$ K. Jaśkowski, Kilka uwag o odszkodowaniu za dyskryminację pracownika (art. $18^{d 3} \mathrm{KP}$ ) ..., s. 174.

${ }^{42}$ Ustawa z dnia 17 listopada 1964 r. - Kodeks postępowania cywilnego (Dz.U. Nr 43, poz. 296 ze zm.).

${ }^{43}$ J. Iwulski, W. Sanetra, Kodeks Pracy. Komentarz ..., s. 150.

${ }^{44}$ A. Jakubecki (red.), Kodeks postępowania cywilnego. Komentarz, Warszawa 2015, s. 610.

${ }^{45}$ M. Muliński, w: A. Góra - Błaszczykowska, Kodeks postępowania cywilnego. Tom I. Komentarz. Art. 1-729, Warszawa 2013, s. 1102.

${ }^{46}$ K. Rączka, w: M. Gersdorf, K. Rączka, M. Raczkowski, Kodeks Pracy. Komentarz, Warszawa 2014, s. 69.
} 
pracodawcy lub osoby, za którą pracodawca ponosi odpowiedzialność z winy umyślnej lub wskutek rażącego niedbalstwa obowiązków wobec pracownika, stwarzające realne zagrożenie istotnych interesów pracownika lub powodujące uszczerbek w tej sferze" ${ }^{\rtimes 7}$. W literaturze podkreśla się, że powstrzymanie się pracodawcy od działań naruszających zasadę równości w zatrudnieniu, jak również podjęcie działań mających na celu zapobieżenie praktykom dyskryminacyjnym w miejscu pracy, jest jednym z podstawowych obowiązków pracodawcy wobec zatrudnionego $^{48}$. Zgodnie $\mathrm{z}$ treścią przepisu, pracownikowi, który rozwiązał umowę we wspomnianym trybie, przysługuje odszkodowanie w wysokości wynagrodzenia za okres wypowiedzenia, a jeżeli umowa o pracę została zawarta na czas określony lub na czas wykonania określonej pracy - w wysokości wynagrodzenia za okres 2 tygodni. Oświadczenie pracownika o rozwiązaniu umowy na podstawie art. $55 \S 1^{1} \mathrm{KP}$ winno być sporządzone na piśmie oraz zawierać przyczynę uzasadniającą rozwiązanie umowy. Jest to konieczne dla ustalenia zasadności rozwiązania stosunku pracy w tym trybie, zgodnie bowiem $\mathrm{z}$ art. $61^{1} \mathrm{KP}$, $\mathrm{W}$ razie nieuzasadnionego skorzystania przez pracownika z omawianego prawa, pracodawca może domagać się odszkodowania przed sądem pracy.

Ponadto, skorzystanie przez pracownika $\mathrm{z}$ prawa do odszkodowania $\mathrm{z}$ art. $18^{3 \mathrm{~d}} \mathrm{KP}$, nie wyklucza domagania się odszkodowania za niezgodne z prawem rozwiązanie umowy o pracę, jeśli przyczyna rozwiązania ma podłoże dyskryminacyjne. Wskazuje się, iż w przypadku zbiegu tych przepisów mamy do czynienia z kumulacją świadczeń majątkowych ${ }^{49}$, bowiem oba roszczenia odszkodowawcze są od siebie odrębne ${ }^{50}$. Dochodzenie przez pracownika roszczeń z tytułu wadliwego wypowiedzenia umowy o pracę nie jest zatem koniecznym warunkiem zasądzenia odszkodowania przewidzianego w art. $18^{3 \mathrm{~d}} \mathrm{KP}^{51}$. W orzecznictwie można się również spotkać ze stanowiskiem przeciwnym, zgodnie z którym dla skutecznego domagania się odszkodowania za naruszenie zasady równego traktowania $\mathrm{w}$ zatrudnieniu, w przypadku gdy naruszenie to polega na rozwiązaniu umowy o pracę $\mathrm{z}$ przyczyn dyskryminacyjnych, konieczne jest wcześniejsze wytoczenie powództwa z art. $45 \S 1 \mathrm{KP}$, bowiem jest to jedyny sposób wykazania przesłanki bezprawności działań pracodawcy. Co więcej, możliwość dochodzenia odszkodowania z art. $18^{3 \mathrm{~d}}$, uzależnia się od zachowania przez pracownika 7-dniowego terminu do złożenia odwołania od wypowiedzenia, liczonego od jego doręczenia. Stanowisko to jest wątpliwe - żaden z przepisów prawa nie wskazuje na taką

\footnotetext{
${ }^{47}$ Wyrok SN z dnia 27 lipca 2012 r., I PK 53/12, OSNP 2013, nr 15-16, poz. 173.

${ }^{48}$ Por. art. 94 pkt 2b KP; również: K. Rączka, w: M. Gersdorf, K. Rączka, M. Raczkowski, Kodeks Pracy. Komentarz ..., s. 69 oraz 495; A. M. Świątowski, Kodeks Pracy. Komentarz ...., s. 320.

${ }^{49}$ M. Gersdorf w: M. Gersdorf, K. Rączka, M. Raczkowski, Kodeks Pracy. Komentarz, s. 504.

${ }^{50}$ Wyrok SN z dnia 3 grudnia 2009 r., II PK 142/09, OSNP 2011, nr 11-12, poz. 153.

${ }^{51}$ Wyrok SN z dnia 14 lutego 2013 r., III PK 31/12, OSNP 2013, nr 23-24, poz. 275.
} 
zależność. Ponadto przyjęcie zaproponowanego stanowiska znacznie osłabiałoby pozycję pracownika w stosunku do pracodawcy.

\section{Podsumowanie}

Podsumowując, obecnie obowiązujące regulacje dotyczące ochrony przed dyskryminacją w zatrudnieniu, zostały wprowadzone w ramach implementacji dyrektyw unijnych. Otwarty katalog przyczyn dyskryminacji oraz roszczenie odszkodowawcze przysługujące pracownikowi za bezprawne naruszenie zasady równego traktowania w zatrudnieniu, zapewniają szeroką i skuteczną ochronę przed naruszeniami. Treść przepisów antydyskryminacyjnych pozwala również na zgodne z prawem różnicowanie sytuacji prawnej pracowników, jeżeli na konieczność taką wskazują obiektywne przesłanki (np. odmienne traktowanie osób niepełnosprawnych czy kobiet w ciąży).

Odpowiedzialność za dyskryminację w zatrudnieniu ponosi pracodawca. Wysokość odszkodowania nie może być niższa niż kwota najniższego wynagrodzenia, de lege lata brak jest górnej granicy wysokości rekompensaty. Wydaje się, że odpowiedzialność odszkodowawcza nie jest zależna od zaistnienia szkody po stronie pracownika ani występowania świadomości naruszenia przepisów prawnych czy winy po stronie pracodawcy. Odszkodowanie, o którym mowa $\mathrm{w}$ art. $18^{3 \mathrm{~d}}$, pełni zarówno funkcję odszkodowania sensu stricto, jak również zadośćuczynienia za doznaną krzywdę. Nie jest ono jedyną konsekwencją, jaka może spotkać pracodawcę za naruszenie zakazu równego traktowania w zatrudnieniu, pracownik może bowiem dochodzić również m.in. odszkodowania za niezgodne z prawem rozwiązanie stosunku pracy, jeśli rozwiązanie takie nastąpiło z przyczyn dyskryminacyjnych. Ochrona ta, jak się wydaje, jest niezależna od dochodzenia roszczeń z art. $45 \S 1 \mathrm{KP}$. Co więcej, osoba zatrudniona może również rozwiązać umowę o pracę bez wypowiedzenia $\mathrm{z}$ powodu ciężkiego naruszenia przez pracodawcę podstawowych obowiązków wobec pracownika.

\section{Bibliografia:}

\section{Literatura}

Baran K. W. (red.), Kodeks Pracy. Komentarz, Warszawa 2014

Czarnecki P., Charakter prawny odszkodowania za dyskryminacje $w$ zatrudnieniu, „Praca i Zabezpieczenie Społeczne" 2012, nr 2

Gersdorf M., Rączka K., Raczkowski M., Kodeks Pracy. Komentarz, Warszawa 2014

Góra - Błaszczykowska A., Kodeks postępowania cywilnego. Tom I. Komentarz. Art. 1-729, Warszawa 2013

Iwulski J, Sanetra W., Kodeks Pracy. Komentarz, Warszawa 2013

Jakubecki A. (red.), Kodeks postępowania cywilnego. Komentarz, Warszawa 2015 
Jaśkowski K., Kilka uwag o odszkodowaniu za dyskryminację pracownika (art. $18^{d 3} \mathrm{KP}$ ), w: $Z$ aktualnych zagadnień prawa pracy $i$ zabezpieczenia spolecznego. Ksiega jubileuszowa profesora Waleriana Sanetry, Białystok 2013

Kędziora K., Śmiszek K., Dyskryminacja i mobbing w zatrudnieniu, Warszawa 2008

Lewandowski M., Ochrona pracownika przed dyskryminacja w polskim prawie pracy, „Palestra” 2014, nr 3-4

Liszcz T., Prawo pracy, Warszawa 2009

Radwański Z., Olejniczak A., Zobowiązania - część ogólna, Warszawa 2012

Romer M. T., Kodeks pracy. Komentarz, Warszawa 2010

Sobczyk A. (red.), Kodeks pracy. Komentarz, , Warszawa 2015

Świątkowski A. M., Kodeks pracy. Komentarz, Warszawa 2012

\section{Orzecznictwo}

Wyrok SN z dnia 3 kwietnia 2008 r., II PK 286/07, OSNP 2009, nr 15-16, poz. 202

Wyrok SN z dnia 7 stycznia 2009 r., III PK 43/08, OSNP 2010, nr 13-14, poz. 160

Wyrok SN z dnia 3 grudnia 2009 r., II PK 142/09, OSNP 2011, nr 11-12, poz. 153

Wyrok SN z dnia 10 maja 2012 r., II PK 227/11, OSNP 2013, nr 9-10, poz. 107

Wyrok SN z dnia 27 lipca 2012 r., I PK 53/12, OSNP 2013, nr 15-16, poz. 173

Wyrok SN z dnia 14 lutego 2013 r., III PK 31/12, OSNP 2013, nr 23-24, poz. 275 